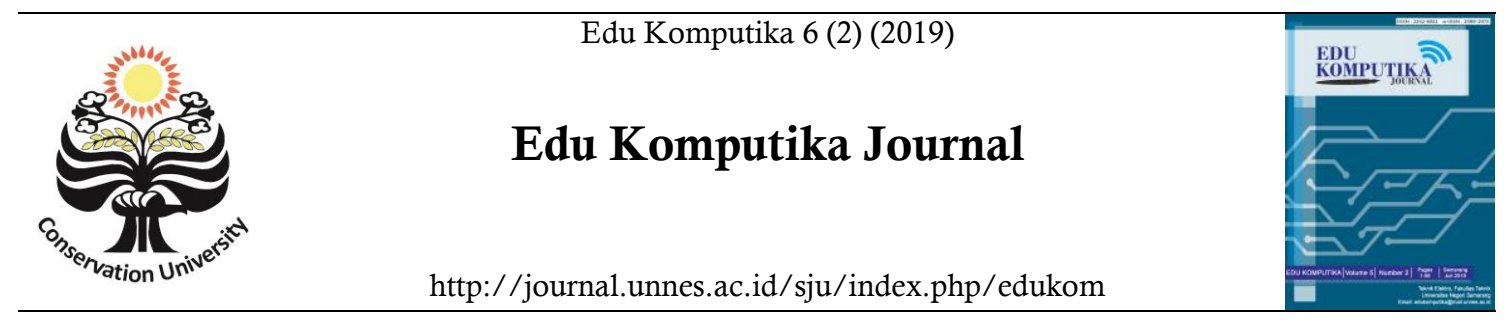

\title{
Penguatan Konsep Pemrograman Berorientasi Objek Siswa Kelas XI RPL SMKN 2 Semarang
}

\section{Seffy Kusuma Ningrum ${ }^{1)}$ dan Djuniadi ${ }^{2) 凶}$}

${ }^{1}$ Sekolah Menengah Kejuruan Negeri 2 Semarang, Indonesia

${ }^{2}$ Jurusan Teknik Elektro, Fakultas Teknik, Universitas Negeri Semarang, Indonesia

\section{Info Artikel}

Sejarah Artikel:

Diterima: November

2019

Direvisi: Desember 2019

Disetujui: Desember 2019

\section{Keywords:}

Pemrograman Berorientasi Objek, Penguatan Konsep

Pemrograman, Hasil

Praktik Pemrograman

\begin{abstract}
Abstrak
Tujuan dari studi ini adalah untuk meningkatkan keterampilan pemrograman berorientasi objek siswa kelas XI RPL SMKN 2 Semarang. Metode yang digunakan adalah studi perbandingan dengan one sample t test. Penelitian ini mempunyai lima tahapan. Tahap pertama melakukan penilaian awal. Tahap kedua melakukan pembelajaran dengan belajar kelompok dan presentasi. Tahap ketiga memberi penugasan. Tahap keempat memberi penguatan konsep alur dan logika pemrograman. Tahap kelima, menyelesaikan kasus pemrograman berorientasi objek. Hasil analisis sebelum perlakuan didapatkan rata-rata nilai 70,74 dengan $t_{\text {hitung }}=0,340$ serta nilai sig $=0,736 \geq 0,05$ sehingga dapat dikatakan bahwa ratarata nilai siswa $=70$. Kalau dilihat dari proporsinya, sampel dengan nilai $<=70$ sebanyak 10 siswa dan sampel dengan nilai $>70$ sebanyak 24 siswa. Hasil analisis setelah perlakuan diskusi kelompok dan presentasi didapatkan rata-rata nilai 84,56 dengan $t_{\text {hitung }}=17,047$ serta nilai sig $=0,00$ sehingga dapat dikatakan bahwa rata-rata nilai siswa $>70$. Sedangkan proporsinya, sampel dengan nilai $>70$ adalah seluruh siswa. Hasil analisis setelah perlakukan penguatan konsep pemrograman didapatkan rata-rata nilai 88,18 dengan $t_{\text {hitung }}=21,424$ serta nilai sig $=$ 0,00 sehingga dapat dikatakan bahwa rata-rata nilai siswa $>70$. Kalau dilihat dari proporsinya sampel dengan nilai $>70$ adalah seluruh siswa. Berdasarkan hasil penelitian dapat disimpulkan bahwa tahapan pembelajaran yang dilakukan mampu meningkatkan ketrampilan pemrograman berorientasi objek siswa.
\end{abstract}

\begin{abstract}
The purpose of the study is to improve the object oriented programming skills of students in class XI RPL at SMKN 2 Semarang. The method used is a comparative study with one sample t test. This research has five stages. The first stage is conducting an initial assessment. The second stage is learning by group study and presentation. The third stage gives assignments. The fourth stage provides reinforcement of the concept of flow and programming logic. The fifth stage, completing the case of object-oriented programming. The results before treatment obtained an average value of 70.74 with $t=0.340$ and sig $=0.736 \geq 0.05$ so that it can be said that the average value of students $=70$. The results after the treatment of group discussions and presentations obtained an average value of 84.56 with $t=17.047$ and sig $=0.00$ so that it can be said that the average value of students $>70$. The proportion, samples with a value $>70$ are all students. The results after the treatment of the strengthening of programming concepts obtained an average value of 88.18 with $t=21.424$ and sig $=0.00$ so that it can be said that the average value of students $>70$. The proportion of samples with a value $>70$ is all students. Based on the results of the study it can be concluded that the stages of learning carried out are able to improve student object oriented programming skills.
\end{abstract}




\section{PENDAHULUAN}

Konsep pemrograman penting bagi siswa Sekolah Menengah Kejuruan, khususnya pemrograman berorientasi objek. Studi tentang peningkatan ketrampilan pemrograman siswa masih menarik untuk diteliti. Sekolah Menengah Kejuruan Negeri 2 Semarang dipilih sebagai tempat penelitian.

Sekolah Menengah Kejuruan Negeri 2 (SMKN 2) Semarang beralamatkan di Jalan Dr. Cipto nomor 121A Semarang. SMKN 2 Semarang menyelenggarakan 5 Kompetensi. Kelima kompetensi yang diselenggarakan yaitu 1) Rekayasa Perangkat Lunak (RPL), 2) Usaha Perjalanan Wisata (UPW), 3) Otomatisasi dan Tata Kelola Perkantoran (OTKP), 4) Akuntasi dan Keuangan Lembaga (AKL), dan 5) Bisnis Daring dan Pemasaran (BDP). Kelas yang diasuh meliputi kelas X, XI dan XII (SMKN 2 Semarang, 2019) (PPDB Online Jateng, 2019). Tampak bahwa RPL kelas XI merupakan salah kelas yang diselenggarakan di SMKN 2 Semarang.

Struktur kurikulum Kelas XI RPL mata pelajaran keahlian yang diberikan meliputi Pemodelan Perangkat Lunak; Basis Data; Pemrograman Berorientasi Objek; Pemrograman Web dan Perangkat Bergerak; serta Produk Kreatif dan Kewirausahaan (Dirjen Dikdasmen, 2018). Pemrograman Berorientasi Objek (PBO) merupakan salah mata pelajaran yang dipelajari oleh siswa kelas XI RPL.

PBO kelas XI RPL semester 1 memberikan penguasaan Kompetensi Dasar meliputi Memahami konsep pemrograman berorientasi objek; Mempresentasikan konsep pemrograman berorientasi objek; Menerapkan dasar dan aturan pemrograman berorientasi objek; Membuat kode program dasar dan aturan pemrograman berorientasi objek; Menerapkan konsep class, method dan object; Membuat class, method dan object; Menerapkan konsep enkapsulasi dalam melindungi data dan informasi; Membuat kode program enkapsulasi dalam melindungi data dan informasi; Menerapkan konsep pewarisan; serta Membuat hubungan antara class dengan pola pewarisan (Direktorat PSMK, 2017) (Patwiyanto, Wahyuni, S., Prasetyo, S.A., 2018).

Persoalan yang dihadapi siswa dalam belajar PBO adalah mereka kesulitan menuangkan persoalan kehidupan nyata kedalam program komputer sebagai solusi. Dampak yang timbul, siswa menghabiskan banyak effort untuk menyelesaikan kasus yang diberikan kepadanya. Hal ini disebabkan lemahnya konsep dasar pemrograman.
PBO adalah pendekatan pemrograman yang menggunakan object dan class. Konsep PBO terus berkembang. Pengembang aplikasi menerapkan konsep PBO tidak sekedar cara menulis sintak program, namun $\mathrm{PBO}$ merupakan cara pandang dalam menganalisa sistem dan persoalan pemrograman. Konsep PBO setiap bagian dari program adalah object. Object mewakili suatu bagian program yang akan diselesaikan (Wibowo, K., 2015).

Java merupakan salah satu bahasa pemrograman yang dapat digunakan untuk mengimplementasikan PBO. Pemrograman desktop lebih mudah untuk dipraktekan oleh siswa. Beberapa konsep dasar java yang dapat dipelajari yaitu Stuktur Pemrograman Java, Tipe Data, Struktur Kontrol, Struktur Data, Modular, dan Kelas Utilitas (Rahmawati, E., 2014).

Konsep dasar pemrograman penting untuk dipahami dan dikuasai siswa. Penguatan konsep dasar pemrograman dilakukan dengan langkah memberikan deskripsi topik yang dibahas; memberikan konsep logika dan alur proses; memberikan ilustrasi proses; serta memberikan contoh penerapan. Apabila siswa mempunyai penguasaan yang baik dalam pemrograman maka mereka dapat berperan sebagai problem solvers.

Penguasaan kemampuan pemrograman dalam kontek belajar dari diukur dengan Kriteria Ketuntasan Minimal (KKM). KKM adalah kriteria ketuntasan belajar. KKM untuk mata pelajaran muatan umum ditentukan oleh satuan pendidikan dan mata pelajaran muatan kejuruan ditentukan oleh satuan pendidikan bersama dengan DUDI dan/atau lembaga terkait (Direktorat Pembinaan SMK, 2017).

Tujuan penelitian adalah melakukan penguatan konsep alur dan logika pemrograman untuk meningkatkan hasil belajar pemrograman berorientasi objek siswa kelas XI RPL SMKN 2 Semarang.

\section{METODE PENELITIAN}

Metode penelitian yang digunakan adalah perbandingan dengan one sample t test (Djuniadi, Afiffudin, M., Lestari, W., 2016). Langkah penelitian yang dilakukan mempunyai lima tahap. Nilai KKM yang digunakan sebesar 70 . Tahap pertama melakukan penilaian awal, dan dilakukan analisis sehingga didapat potret awal sampel sebelum perlakuan. Sampel penelitian sejumlah 34 siswa kelas XI Kompetensi Rekayasa Perangkat Lunak (RPL) Sekolah Menengah Kejuruan Negeri (SMKN) 2 Semarang. 
Tahap kedua melakukan pembelajaran dengan membentuk 7 kelompok. Setiap kelompok beranggotakan 5 siswa. Selanjutnya semua kelompok diberi tugas untuk mendiskusi topik pemrograman berorientasi objek dasar. Kemudian setiap kelompok diminta untuk mempresentasikan hasil diskusi. Kelompok yang lain berperan sebagai penanya atau pembahasnya. Sehingga terjadi diskusi yang dinamis dan konstruktif.

Tahap ketiga, setiap siswa diberi tugas untuk diselesaikan di rumah dan dikumpulkan pada pertemuan berikutnya. Kemudian dilakukan penilaian terhadap tugas siswa. Selanjutnya dilakukan analisis untuk mendapatkan potret dampak perlakukan diskusi kelompok dan maju presentasi terhadap hasil penugasan siswa.

Tahap keempat, siswa diberi penguatan konsep alur dan logika pemrograman. Sehingga siswa mempunyai konsep, filosofi dan pengalaman pemrograman yang kuat.

Tahap kelima, siswa diberi tugas untuk menyelesaikan kasus pemrograman berorientasi objek. Kemudian hasilnya dinilai dan selanjutnya dianalisis untuk melihat dampak penguatan konsep pemrograman terhadap kemampuan praktik siswa.

\section{HASIL DAN PEMBAHASAN}

Data yang didapatkan pada setiap tahapan kemudian dianalisis dengan bantuan program analisis data SPSS 16. Perlakukan diberikan pada tahap kedua dan keempat. Analisis data dilakukan pada tahap pertama, ketiga dan tahap kelima.

\section{Hasil Analisis Data Tahap Pertama}

Tabel 1. Tahap Pertama - One-Sample Statistics

\begin{tabular}{|c|c|c|c|c|}
\hline & $N$ & Mean & $\begin{array}{c}\text { Std. } \\
\text { Deviation }\end{array}$ & $\begin{array}{c}\text { Std. Error } \\
\text { Mean }\end{array}$ \\
\hline $\begin{array}{l}\text { HASIL } \\
\text { BELAJAR }\end{array}$ & 34 & 70,7353 & 12,60425 & 2,16161 \\
\hline
\end{tabular}

Tabel 2. Tahap Pertama - One-Sample Test

\begin{tabular}{|c|c|c|c|c|c|}
\hline & \multicolumn{5}{|c|}{ Test Value $=70$} \\
\hline & \multirow[b]{2}{*}{$t$} & \multirow{2}{*}{$\begin{array}{c}\text { Sig. } \\
(2- \\
d f \text { tailed }) \\
\end{array}$} & \multirow{2}{*}{$\begin{array}{c}\text { Mean } \\
\text { Difference }\end{array}$} & \multicolumn{2}{|c|}{$\begin{array}{c}95 \% \text { Confidence } \\
\text { Interval of the } \\
\text { Difference }\end{array}$} \\
\hline & & & & Lower & Upper \\
\hline $\begin{array}{l}\text { HASIL } \\
\text { BELAJAR }\end{array}$ & .3433 & .736 & .7353 & -3.663 & 5.133 \\
\hline
\end{tabular}

Berdasarkan tabel 1, hasil analisis sebelum perlakuan didapatkan rata-rata nilai 70,74. Perhatikan tabel 2, didapatkan $t_{\text {hitung }}=0,340$ serta nilai sig $=0,736 \geq 0,05$ sehingga dapat dikatakan bahwa rata-rata nilai siswa $=70$. Kalau dilihat dari proporsinya (perhatikan tabel 3), sampel dengan nilai $<=70$ sebanyak 10 siswa dan sampel dengan nilai $>70$ sebanyak 24 siswa.

Tabel 3. Tahap Pertama - Binomial Test

\begin{tabular}{|c|c|c|c|c|c|}
\hline & Category & $N$ & $\begin{array}{l}\text { Obser- } \\
\text { ved } \\
\text { Prop. }\end{array}$ & $\begin{array}{l}\text { Test } \\
\text { Prop. }\end{array}$ & $\begin{array}{l}\text { Asymp. } \\
\text { Sig. (1- } \\
\text { tailed) }\end{array}$ \\
\hline \multirow{3}{*}{$\begin{array}{l}\text { HASIL } \\
\text { BELA- } \\
\text { JAR }\end{array}$} & Group $1<=70$ & 10 & 0,3 & 0,2 & 0,125 \\
\hline & Group $2>70$ & 24 & 0,7 & & \\
\hline & Total & 34 & 1,0 & & \\
\hline
\end{tabular}

\section{Hasil Analisis Data Tahap Ketiga}

Tabel 4. Tahap Ketiga - One-Sample Statistics

\begin{tabular}{lcccc}
\hline & & & \multicolumn{2}{c}{ Std. } \\
& $N$ & Mean & $\begin{array}{c}\text { Std. Error } \\
\text { Deviation }\end{array}$ & Mean \\
\hline NILAI & 34 & 84,5588 & 4,97991 & 0,85405 \\
TUGAS & & & & \\
\hline
\end{tabular}

Tabel 5. Tahap Ketiga - One-Sample Test

\begin{tabular}{|c|c|c|c|c|c|c|}
\hline & \multicolumn{6}{|c|}{ Test Value $=70$} \\
\hline & \multirow[b]{2}{*}{$t$} & \multirow{2}{*}{\multicolumn{2}{|c|}{$\begin{array}{cc} & \text { Sig. } \\
& (2- \\
& \text { taile } \\
d f & d)\end{array}$}} & \multirow{2}{*}{$\begin{array}{c}\text { Mean } \\
\text { Difference }\end{array}$} & \multicolumn{2}{|c|}{$\begin{array}{l}\text { 95\% Confidence } \\
\text { Interval of the } \\
\text { Difference }\end{array}$} \\
\hline & & & & & Lower & Upper \\
\hline $\begin{array}{l}\text { NILAI } \\
\text { TUGAS }\end{array}$ & 17,047 & 33 & 0,00 & 14,5589 & 12,8213 & 16,2964 \\
\hline
\end{tabular}

Berdasarkan tabel 4, 5 dan tabel 6 hasil analisis setelah perlakuan diskusi kelompok dan presentasi didapatkan rata-rata nilai 84,56 dengan $t_{\text {hitung }}=17,047$ serta nilai sig $=0,00$ sehingga dapat dikatakan bahwa rata-rata nilai siswa $>70$. Kalau dilihat dari proporsinya, sampel dengan nilai $>70$ adalah seluruh siswa.

Tabel 6. Tahap Ketiga - Binomial Test

\begin{tabular}{|c|c|c|c|c|c|c|}
\hline & & Category & $N$ & $\begin{array}{c}\text { Observed } \\
\text { Prop. }\end{array}$ & $\begin{array}{l}\text { Test } \\
\text { Prop. }\end{array}$ & $\begin{array}{l}\text { Asymp. } \\
\text { Sig. (1- } \\
\text { tailed) }\end{array}$ \\
\hline \multirow{3}{*}{$\begin{array}{l}\text { NILAI } \\
\text { TUGA } \\
\text { S }\end{array}$} & $\begin{array}{l}\text { Group } \\
1\end{array}$ & $<=70$ & 0 & 0,0 & 0,2 & 0,001 \\
\hline & $\begin{array}{l}\text { Group } \\
2\end{array}$ & $>70$ & 34 & 1,0 & & \\
\hline & Total & & 34 & 1,0 & & \\
\hline
\end{tabular}




\section{Hasil Analisis Data Tahap Kelima}

Tabel 7. Tahap Kelima - One-Sample Statistics

\begin{tabular}{|c|c|c|c|c|}
\hline & $N$ & Mean & $\begin{array}{c}\text { Std. } \\
\text { Deviation }\end{array}$ & $\begin{array}{c}\text { Std. Error } \\
\text { Mean }\end{array}$ \\
\hline $\begin{array}{l}\text { NILAI } \\
\text { PRAKTEK }\end{array}$ & 34 & 89,1765 & 5,21926 & 0,89510 \\
\hline
\end{tabular}

Tabel 8. Tahap Kelima - One-Sample Test

\begin{tabular}{|c|c|c|c|c|c|c|}
\hline & \multicolumn{6}{|c|}{ Test Value $=70$} \\
\hline & \multirow[b]{2}{*}{$t$} & \multirow{2}{*}{$d f$} & \multirow{2}{*}{$\begin{array}{l}\text { Sig. } \\
(2- \\
\text { taile } \\
\text { d) }\end{array}$} & \multirow{2}{*}{$\begin{array}{c}\text { Mean } \\
\text { Difference }\end{array}$} & \multicolumn{2}{|c|}{$\begin{array}{c}\text { 95\% Confidence } \\
\text { Interval of the } \\
\text { Difference }\end{array}$} \\
\hline & & & & & Lower & Upper \\
\hline $\begin{array}{l}\text { NILAI } \\
\text { PRAK- } \\
\text { TEK }\end{array}$ & 21,424 & 33 & 0,00 & 19,1765 & 17,356 & 20,998 \\
\hline
\end{tabular}

Berdasarkan tabel 7, hasil analisis setelah perlakukan penguatan konsep pemrograman didapatkan rata-rata nilai 88,18 . Perhatikan tabel 8 , besarnya $t_{\text {hitung }}=21,424$ serta nilai sig $=0,00$ sehingga dapat dikatakan bahwa rata-rata nilai siswa $>70$. Perhatikan tabel 9, kalau dilihat dari proporsinya sampel dengan nilai $>70$ adalah seluruh siswa.

Tabel 9. Tahap Kelima - Binomial Test

\begin{tabular}{|c|c|c|c|c|c|}
\hline & & Category & $N$ & $\begin{array}{c}\text { Obser- } \\
\text { ved } \\
\text { Prop. Prop. }\end{array}$ & $\begin{array}{l}\text { Asymp. } \\
\text { Sig. (1- } \\
\text { tailed) }\end{array}$ \\
\hline \multirow{3}{*}{$\begin{array}{l}\text { NILAI } \\
\text { PRAK- } \\
\text { TEK }\end{array}$} & Group 1 & $<=70$ & 0 & 0,0 & 0,001 \\
\hline & Group 2 & $>70$ & 34 & 1,0 & \\
\hline & Total & & 34 & 1,0 & \\
\hline
\end{tabular}

\section{SIMPULAN}

Berdasarkan hasil analisis data didapat peningkatan ketrampilan yang signifikan terhadap hasil belajar pemrograman berorientasi objek siswa kelas XI RPL SMKN 2 Semarang. Hal ini ditandai dengan peningkatan rata-rata nilainya. Sebelum perlakuan rata-rata nilai sampel sebesar 70,74. Setelah perlakuan diskusi kelompok dan presentasi didapatkan rata-rata nilai sampel sebesar 84,56 dengan $t_{\text {hitung }}=17,047$ serta nilai sig $=0,00$ sehingga dapat dikatakan bahwa rata-rata nilai siswa $>70$. Sedangkan setelah perlakukan penguatan konsep pemrograman didapatkan rata-rata nilai sampel sebesar 88,18 sedangkan $t_{\text {hitung }}=21,424$ serta nilai $\operatorname{sig}=0,00$ sehingga dapat dikatakan bahwa ratarata nilai siswa $>70$ dan proporsi sampel dengan nilai $>70$ adalah seluruh siswa. Sehubungan dengan itu dapat disimpulkan bahwa tahapan pembelajaran yang dilakukan mampu meningkatkan ketrampilan pemrograman berorientasi objek siswa.

\section{SARAN}

Berdasarkan penelitian yang telah dilakukan dapat disarankan untuk melakukan penelitian yang lebih komprehensip sehingga didapatkan hasil yang lebih akurat.

\section{UCAPAN TERIMA KASIH}

Ucapan terima kasih ditujukan kepada TIM PDS Unnes yang telah memberikan kesempatan untuk melakukan pembelajaran dan penelitian di SMK Negeri 2 Semarang.

\section{DAFTAR PUSTAKA}

Direktorat Pembinaan SMK, 2017. Panduan penilaian hasil belajar pada sekolah menengah kejuruan. Jakarta: Kementerian Pendidikan Dan Kebudayaan.

Direktorat PSMK, 2017. KI/KD SMK/MAK Kompetensi Keahlian Rekayasa Perangkat Lunak. Jakarta: Kementerian Pendidikan Dan Kebudayaan.

Dirjen Dikdasmen, 2018. Struktur kurikulum sekolah menengah kejuruan (SMK) / madrasah aliyah kejuruan (MAK). Jakarta: Kementerian Pendidikan Dan Kebudayaan.

Djuniadi, Afiffudin, M., Lestari, W., 2016. Statistik Inferensial: Teori, Aplikasi dan Latihan Soal dengan SPSS. Semarang: Program Pascasarjana Universitas Negeri Semarang.

Patwiyanto, Wahyuni, S., Prasetyo, S.A., 2018. Pemrograman Berorientasi Objek SMK/MAK Kelas XI. Yogyakarta: Andi.

PPDB Online Jateng, 2019. Website Pendaftaran Peserta Didik Baru Online Jawa Tengah. URL: https://jateng.siapppdb.com

Rahmawati, E., 2014. Perancangan Platform Virtual Java Programming Laboratory (VJP-LAB) Sebagai Sarana Penguatan Konsep Dasar Pemrograman Java. 
Jurnal Link Vol 20 No. 1 Hal: 5-24 - 5-

28.

SMKN 2 Semarang, 2019. Website Sekolah Menengah Kejuran Negeri 2 Semarang. URL: http://smknegeri2smg.sch.id/

Wibowo, K., 2015. Analisa konsep object oriented programming pada bahasa pemrograman PHP. Jurnal khatulistiwa informatika, vol. 3 , no. 2 hal: 151-159. 